\title{
The Potential Phosphorus Crisis: Resource Conservation and Possible Escape Technologies: A Review
}

\author{
Saba Daneshgar ${ }^{1}$, Arianna Callegari ${ }^{1}$, Andrea G. Capodaglio ${ }^{1, * \text { (i) }}$ and David Vaccari ${ }^{2}$ (D) \\ 1 Department of Civil Engineering and Architecture, University of Pavia, 27100 PAVIA, Italy; \\ saba.daneshgar@unipv.it (S.D.); arianna.callegari@unipv.it (A.C.) \\ 2 Department of Civil, Environmental and Ocean Engineering, Stevens Institute of Technology, Hoboken, \\ NJ 07030, USA; dvaccari@stevens.edu \\ * Correspondence: andrea.capodaglio@unipv.it or capo@unipv.it; Tel.: +39-038-298-5591
}

Received: 4 April 2018; Accepted: 28 May 2018; Published: 2 June 2018

\begin{abstract}
Phosphorus is an essential nutrient for every organism on the Earth, yet it is also a potential environmental pollutant, which may cause eutrophication of water bodies. Wastewater treatment plants worldwide are struggling to eliminate phosphorus from effluents, at great cost, yet current research suggests that the world may deplete the more available phosphorus reserves by around 2300. This, in addition to environmental concerns, evokes the need for new phosphorus recovery techniques to be developed, to meet future generations needs for renewable phosphorus supply. Many studies have been, and are, carried out on phosphorus recovery from wastewater and its sludge, due to their high phosphorus content. Chemical precipitation is the main process for achieving a phosphorus-containing mineral suitable for reuse as a fertilizer, such as struvite. This paper reviews the current status and future trends of phosphorus production and consumption, and summarizes current recovery technologies, discussing their possible integration into wastewater treatment processes, according to a more sustainable water-energy-nutrient nexus.
\end{abstract}

Keywords: phosphorus; scarcity; nitrogen; wastewater; eutrophication; recovery

\section{Introduction}

Phosphorus $(\mathrm{P})$ is a non-metal in the 15th group of the periodic table or "nitrogen family" and is one of the most indispensable materials for everyday life, affecting each and every organism on Earth. The elemental form of phosphorus can be mainly found in two different physical forms; white (or yellow) phosphorus and red phosphorus. These two allotropes have miscellaneous physical and chemical characteristics. White phosphorus, which is widely in the form $\mathrm{P}_{4}$, has considerably high reactivity, due to its tetrahedral structure causing ring strain. On the contrary red phosphorus is present as polymeric chains $\left(\mathrm{P}_{\mathrm{n}}\right)$ and due to that, shows more stability [1]. Red phosphorus can be transformed into white phosphorus by heating it up to $300^{\circ} \mathrm{C}$ in the absence of oxygen, or under direct exposure to sunlight. Phosphorus, however, is never found free in its elemental form in nature due to its high reactivity; instead, phosphorus-containing minerals (mainly as phosphate) are dispersed worldwide, predominantly in sedimentary rocks. P-containing minerals may store notable amounts of phosphate, usually $15-20 \%$. This leads to a phosphate rock P content close to $2.7-3.7 \%$ by weight (phosphate minerals comprise approximately $18.5 \% \mathrm{P}$ by weight), which is remarkable, considering that the typical sedimentary rock only contains about $0.2 \% \mathrm{P}(w / w)$. 
Phosphorus is a vital component of all living organisms, as it a building substance of DNA and RNA (in form of phosphate ion $\mathrm{PO}_{4}{ }^{3-}$ ), plays essential roles in energy transfer through living cells as a component of adenosine triphosphate (ATP) and, as phospholipids, contributes to the formation of cell membranes. Besides that, a considerable amount of phosphorus is contained in living beings' bodies, mainly in bones and teeth, mostly as calcium hydroxyapatite $\mathrm{Ca}_{10}\left(\mathrm{PO}_{4}\right)_{6}(\mathrm{OH})_{2}$ [2]. Around $650 \mathrm{~g}$ of phosphorus can be found in the average human body [3]; only its calcium content, apart from the four organic elements of oxygen, carbon, hydrogen and nitrogen, is higher than that.

Phosphorus has no stable gaseous form and, because of this, only appears in the atmosphere adsorbed on particulate matter, which is rapidly removed from the atmosphere by precipitation, either wet or dry, processes. Therefore, the amount of $\mathrm{P}$ present in the atmosphere at any time is low. However, studies on the presence of phosphine $\left(\mathrm{PH}_{3}\right)$ gas, which is known as a trace atmospheric gas constituent, were recently carried out [4]. Phosphine is a volatile, toxic gas that can be found around the globe at different, usually very low, concentrations. This is due to the fact that this compound can be oxidized very easily in air [5]. While it is believed that phosphine may have an important role in the biogeochemical phosphorus cycle [4], there is still a need for more extended studies on its origins and impacts on such cycle. In soils, however, phosphorus is widely present in different forms; soluble, mineral, adsorbed and organic. The soluble fraction represents a very low percentage of total $\mathrm{P}$, but it is the only form (free orthophosphate ions $\mathrm{PO}_{4}{ }^{3-}$ ) that plants and crops can use for growth. Insoluble $\mathrm{P}$, which consists of organic and mineral $\mathrm{P}$, is instead the dominant $\mathrm{P}$ form in soils: the dominance of aluminum/iron phosphates and calcium phosphate forms limits its solubility in acid and alkaline soils, respectively. Phosphate forms excreted by living organisms are released in soils as organic phosphates. These are then broken down to inorganic fraction by microorganisms during a long mineralization process. Activity of these microorganisms is highly dependent on soil temperature and moisture content. Hence, being the amount of soluble P in soils quantitatively negligible, total phosphorus (TP) is almost solely dependent on its mineral, adsorbed and organic fractions. In aquatic environments, to relatively low concentrations of $\mathrm{Al} / \mathrm{Fe} / \mathrm{Ca}$ ions, $\mathrm{P}$ ions are much more available than in soils. Industrial wastes, detergents and domestic sewage are considerable sources of phosphate ions to waters, therefore high available amounts of phosphate ions, could stimulate growth of plants and phytoplankton in water bodies.

This paper summarizes the most recent information about phosphorus use trends and resources forecasting and discusses some of the proposed technologies for recovery of this essential element from wastewater.

\section{Phosphorus Rock Reserves}

Phosphorus is distributed around the world mostly in the form of minerals contained in sedimentary rocks (very little is of igneous origin); however, high-quality deposits that are de facto economically exploitable are not homogeneously available. Sedimentary deposits are formed from a combination of physical and chemical conditions associated with coastal upwelling zones, coupled with geological sea level changes. The rare combination of these conditions makes phosphate deposits unevenly distributed around the world. As a result, "few prospects exist for new discoveries of phosphate rock" [6]. This is consistent with the very few significant increases in known P reserves in the last century, and only in a few locations in the world [7], as shown in Figure 1. 


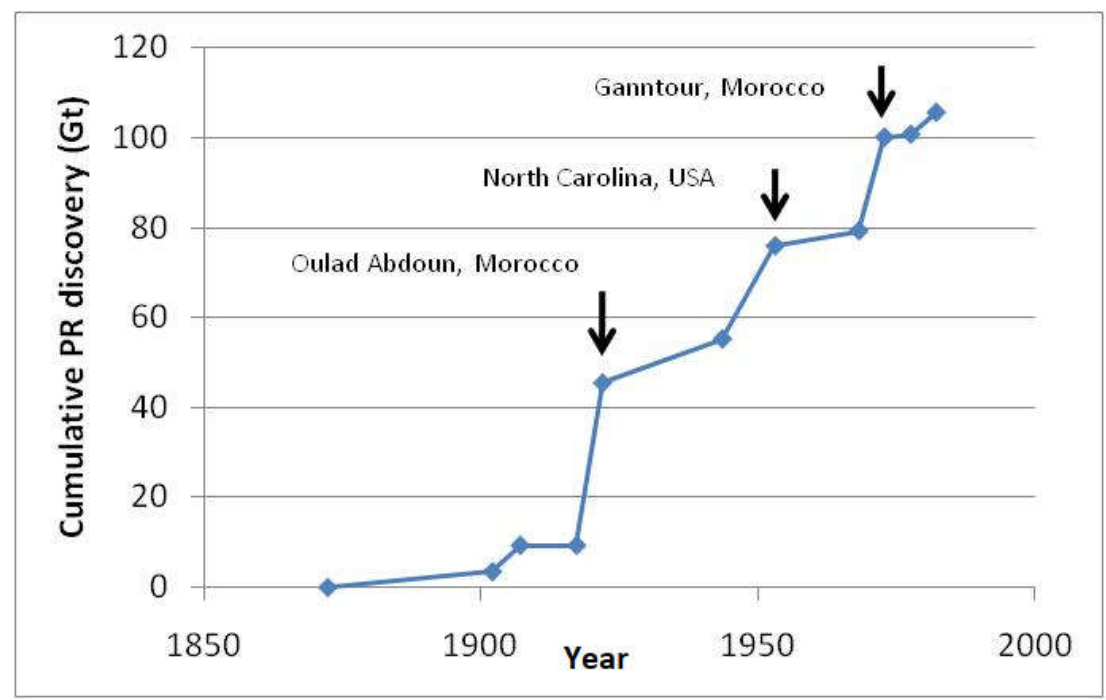

Figure 1. Discovery of phosphate rock reserves in the last century (based on [7]). The y-axis indicates the cumulative amount of $P$ reserves discovered up to the year on the x-axis.

The most common group of phosphorus-containing minerals is apatite. Apatite minerals are calcium phosphate compounds ( 5 calcium ions bonded to three phosphate ions) bonded to one of the $\mathrm{F}^{-}, \mathrm{Cl}^{-}$or $\mathrm{OH}^{-}$ions, commonly known as fluorapatite, chlorapatite and hydroxyapatite. Among these, fluorapatite $\left(\mathrm{Ca}_{5}\left(\mathrm{PO}_{4}\right)_{3} \mathrm{~F}\right)$ constitutes the largest amount of deposits of currently mined phosphate rocks. Phosphate rocks may contain some impurities, as well: of particular concern are cadmium and radionuclides including uranium and its decay products.

The application of phosphate-containing minerals can be categorized in two main streams: agricultural and nonagricultural. About $95 \%$ of all TP production around the world is utilized in the agricultural sector, mainly as fertilizers. Phosphorus and nitrogen are the two most important elements used in the inorganic fertilizers industry. In addition to fertilizers, P-containing minerals are also used in animal feed additives production.

In the nonagricultural sector, phosphorus is used in wide range of applications, from the food sector (as additives, i.e., polyphosphates) to actual industrial use, to preparation of household products. Soft drinks ingredients, detergents and cleansers, metal surface treatment and corrosion inhibition are just some examples of the many possible applications of this element. It is, however, important to emphasize that these constitute less than $5 \%$ of TP consumption in the world.

\subsection{Current Phosphorus Production, Consumption and Resources}

Phosphate rock as taken out of the ground, if it contains enough $\mathrm{P}$ to be considered as a usable source, is called ore. Ore is subjected to initial processing called beneficiation, which increases its purity: in a sedimentary phosphate ore, for example, beneficiation will remove much of the associated sand and clay. The resulting product is called phosphate rock (PR).

Traditionally, chemists used a weighting method for the determination of phosphorus content in fertilizers, in terms of $\mathrm{P}_{2} \mathrm{O}_{5}$. Nowadays, $\mathrm{P}$ content is still conventionally expressed in $\mathrm{P}_{2} \mathrm{O}_{5}$ equivalent: phosphate rock typically contains $30-32 \% \mathrm{P}_{2} \mathrm{O}_{5}$ and, since $\mathrm{P}_{2} \mathrm{O}_{5}$ itself consists of $43.6 \% \mathrm{P}$, this range corresponds nominally to $13-14 \% \mathrm{P}$, by weight.

According to the International Fertilizer Association (IFA) [8] data, world total PR production in 2014 was around $197 \mathrm{Mt}$ PR. Assuming a nominal 30\% $\mathrm{P}_{2} \mathrm{O}_{5}$ content, this would correspond to about $26 \mathrm{Mt} \mathrm{P}$, with the biggest share produced in East Asia ( $42 \%$, mainly in China), followed by North Africa (Morocco) and North America (US), with 21\% and 14\% respectively. Figure 2 illustrates regional shares of PR production in 2014. In the late 1980s, a peak in PR mining was observed, due to an excessive 
fertilizers' use in the Soviet Union during those years, which was then followed by a considerable use decrease in the early 1990s (Figure 3). The latter occurred due to reduction of inorganic fertilizer use by developed countries, due to new awareness of phosphorus harmful effects on the environment, and especially to reduced fertilizers demand following the dissolution of the Soviet Bloc [9]. In the last decade, however, increased per-capita demand by developing countries due to dietary changes brought by increased generalized wealth, coupled with steady global population increase, has resulted in unprecedented levels of fertilizers production and consumption.

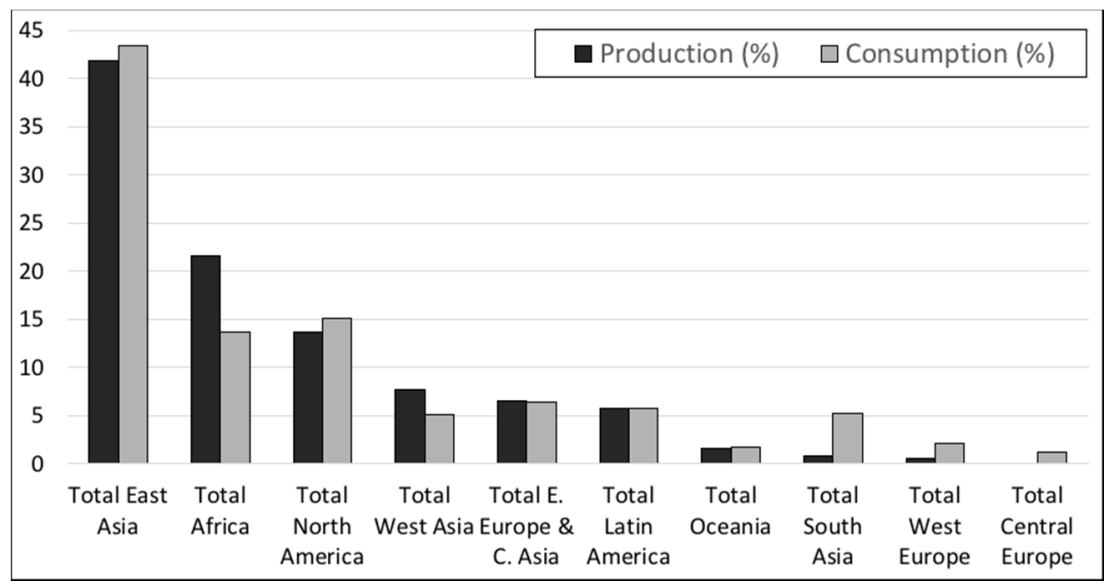

Figure 2. Global P production and consumption shares (based on [8]).

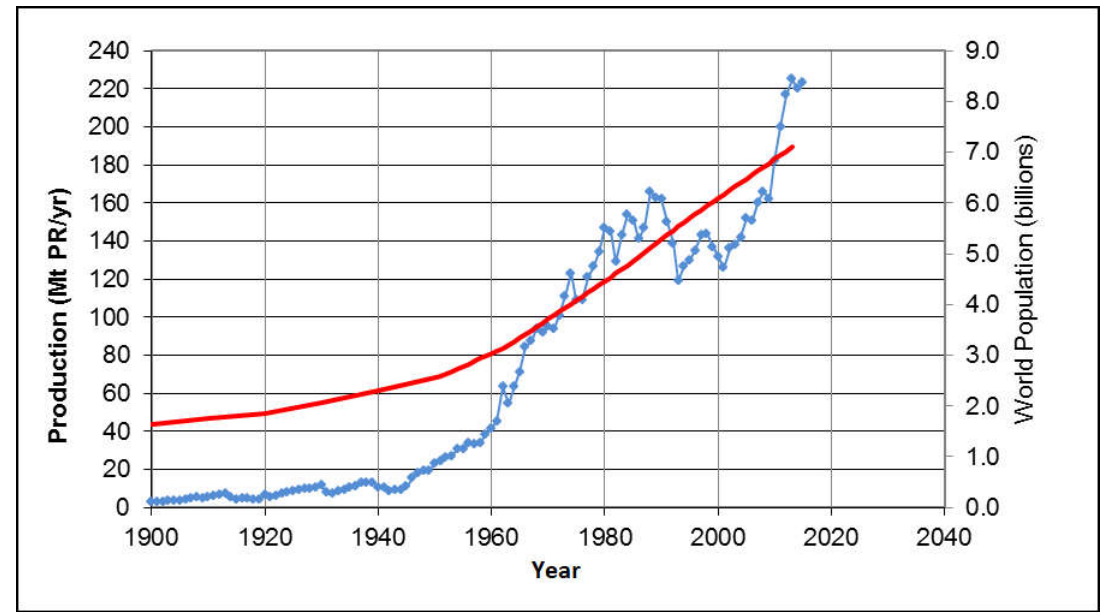

Figure 3. Global production of phosphate rock (blue) coupled with world population (red) in time [10].

World total phosphate rock reserves in 2014 (Table 1) were reported as 68,776 Mt (about $9000 \mathrm{Mt}$ as P), of which 73\% (50,000 Mt) just in Morocco and Western Sahara [11]. China currently holds the second biggest global reserves at $3700 \mathrm{Mt} P R$, which however represent only $5.4 \%$ of the world total. Figure 4 shows the geographical distribution of phosphate rock reserves [11]. Although total global phosphate resources are estimated at more than 300 billion tonnes, a great part of these are not available for extraction under current economic and technological conditions. For instance, deposits comparable to present Moroccan reserves have been detected in the continental shelves of the Atlantic and Pacific Oceans [12]; however, at the moment there is no economically profitable method for ocean mining, and the exploitation of these deposits remains prohibitive for reasonable consideration. 
Table 1. PR production and reserves as beneficiated PR, 2014 data (based on [11]).

\begin{tabular}{cccccc}
\hline \multirow{2}{*}{ Source } & \multicolumn{2}{c}{ Production } & \multicolumn{2}{c}{ Reserves } & R/C \\
\cline { 2 - 6 } & $\mathbf{( M t / y r )}$ & $\mathbf{( \% )}$ & $\mathbf{( M t )}$ & $\mathbf{( \% )}$ & $\mathbf{( y r s )}$ \\
\hline Morocco \& Western Sahara & 30 & 13 & 50,000 & 73 & 1667 \\
China & 100 & 45 & 3700 & 5.4 & 37 \\
United States & 25.3 & 12 & 1100 & 1.6 & 40 \\
MENA-M/WS & 25.7 & 12 & 8166 & 12 & 318 \\
Rest of the world & 37.2 & 17 & 5810 & 8 & 156 \\
World total & 218 & & 68,776 & & 315 \\
As P ${ }^{* *}$ & 28.6 & & 9005 & \\
\hline
\end{tabular}

$\mathrm{Mt}=$ megatonnes $=$ million metric tonnes $=\mathrm{Tg} .{ }^{*}$ Middle East and North Africa not including Morocco and Western Sahara. ** Assuming PR is $30 \% \mathrm{P}_{2} \mathrm{O}_{5}$. NOTE: USGS data differ from IFA estimates [8] about total world PR production, however, data shown herein are internally consistent (i.e., are related to the same set).

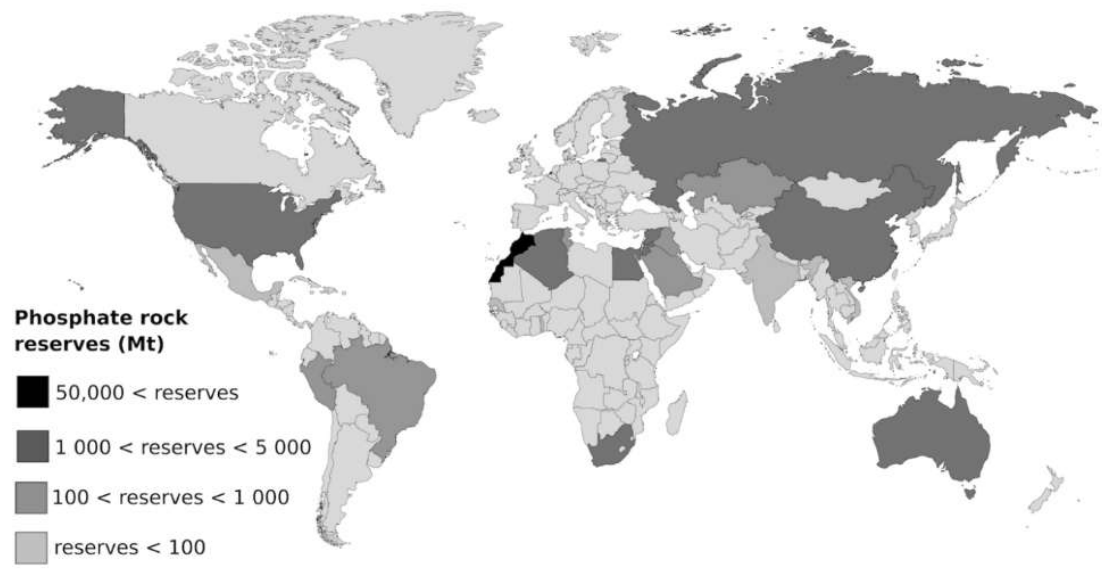

Figure 4. Geographical distribution of the world's known PR reserves (based on [11]).

North Africa, based on high production from its huge amount of reserves, has the highest export of phosphate worldwide, representing nearly $53 \%$ of all imports by other regions [8]. North America, in spite of a high production rate and a still considerable amount of reserves, is highly dependent on imports, due to the declining internal availability of PR and the Country's high consumption rate. Also, East Asian Countries, despite substantial amounts of PR production, have high consumption rates due to high population, which leads the region to import. Worldwide, however, Europe is the region most dependent on imports, which represent $86 \%$ of its total demand [8] since local production is very low. The uneven global distribution of reserves, production control and population growth could therefore potentially induce critical and unprecedented international tensions, when the perception of the "announced" P crisis will hit the public.

\subsection{Future Trends}

Phosphate rock is a finite, irreplaceable, nonrenewable resource [13]. The future trend of PR production and consumption and, consequently, the question of whether (and when) it will be totally depleted in the future, is currently one of the most controversial issues among researchers. As global population is expected to grow drastically, demand for phosphorus will increase due to the unavoidable need to produce more food. Nevertheless, there is still a huge amount of phosphate resources unexploited because of the lack of feasible and not over-expensive methods to extract them. Generally, there are two main views which address the issue of phosphorus scarcity [14].

The first view claims that the rate of consumption will eventually regulate the rate of reserve depletion, leading to a fairly static reserve situation. Forecasting approaches based on this assumption are the "ratio of reserves to consumption" ( $\mathrm{R} / \mathrm{C}$ ratio) to estimate the "lifetime" of available reserves. 
This of course assumes that both numerator and denominator are static, both of which are highly unlikely assumptions. Nevertheless, applying the R/C ratio could be useful as a general indication of when concern about resources could be warranted.

Before 2010 the R/C ratio for global phosphorus was estimated at just over a century [15]. However, in that year the International Fertilizer Development Center (IFDC) published revised estimates that were much larger than the previous [16]. According to some researchers, this "expansion" of reserve estimates does not have a strongly proven basis [17], nevertheless it has been accepted by most global institutions concerned. Accounting for the new estimates, the $\mathrm{R} / \mathrm{C}$ ratio stands now at almost 300 years, a slightly reassuring figure. It might however be considered that any foreseen timeline for depletion, short of a very, very long time should be worrisome, and suggests that, at the very least, present wasteful use should be controlled, and actions for recovery researched and implemented.

Interestingly, the expanded estimate of global PR reserves is based largely on a paper published by the Morocco Phosphate Company, (OCP SA) [18]. It is, however, also interesting to note that, in 2006, the president and CEO of the same company stated: "With the anticipated requirements for phosphate for agricultural and industrial uses, the world is likely to run out in the near future of low-cost recoverable phosphate rock" [19].

Another forecasting approach, with underlying assumptions similar to the former, consists of the application of the Hubbert Curve [13]. This is based on the assumption that PR production will follow a Gaussian distribution, peaking when half of the reserves are consumed. This point is called "peak phosphorus". Cordell et al. [20] predicted that peak phosphorus would occur around year 2035. When the revised reserve numbers were included, the peak was extended only to around 2070. The peak phosphorus concept has been criticized from several points of view. Mew [21], pointed out that the Hubbert Curve is intended to be applied to resources, such as oil, for which there are other feasible alternatives. Thus, the method may be considered to be useful for modeling production from an individual source (such as one country), for which other countries may serve as alternative sources. Its application to global production, whether for phosphorus or oil, has never been scientifically validated. Vaccari and Strigul [22] show that the Hubbert curve worked when applied to USA PR production, but that the peak could not have been accurately "predicted" until after it had occurred! As Mew points out, these criticisms do not contradict the need to start a global discussion on how humanity could "use the finite resources of phosphate that exist, in the most efficient way possible." On the other side, the second approach criticizes the first one in some aspects. Primarily, it points out that this only considers PR proven reserves, and not other possible resources in estimating available phosphorus. Scholz and Wellmer [23] point out that resources that are unexploitable under current economic and technological conditions may become available in the future. While this cannot be denied a priori, it could also be said that, dealing with an irreplaceable and essential resource, it would be at least prudent to act on the basis of current conditions and available knowledge.

Both sides of the debate, however, recognize that phosphorus scarcity is not only dependent on just the rate of resources depletion. Other factors such as potential geopolitical instability of supplier countries, market price, time and effort it takes to extract phosphate rock, all of which lead PR to have highly variable value in the global society, are of great importance.

The historical trends of PR production should become clearer examining global production trends (Figure 3), from which the per capita production illustrated in Figure 5 can be derived. Some of the interesting historical events that become evident from Figure 5 are:

(1) There was a large per-capita PR increase after World War II through the 1970s, which could be attributed to the "green revolution" of the time;

(2) These high levels stabilized from 1975 to 1991 at an average of $30.1 \mathrm{~kg}$ PR per capita, per year;

(3) This was followed by a $24 \%$ reduction for reasons described in Section 2.1, to about $22.8 \mathrm{~kg}$ $\mathrm{PR} /$ cap/yr from 1993 to 2006; 
(4) In the last decade, the per capita consumption recovered to about $31.0 \mathrm{~kg} P R / c a p / y r$. This may be due to improved diet in historically undernourished regions, and due to an increased amount of meat in the diet of nations such as China that have experienced rapid economic development.

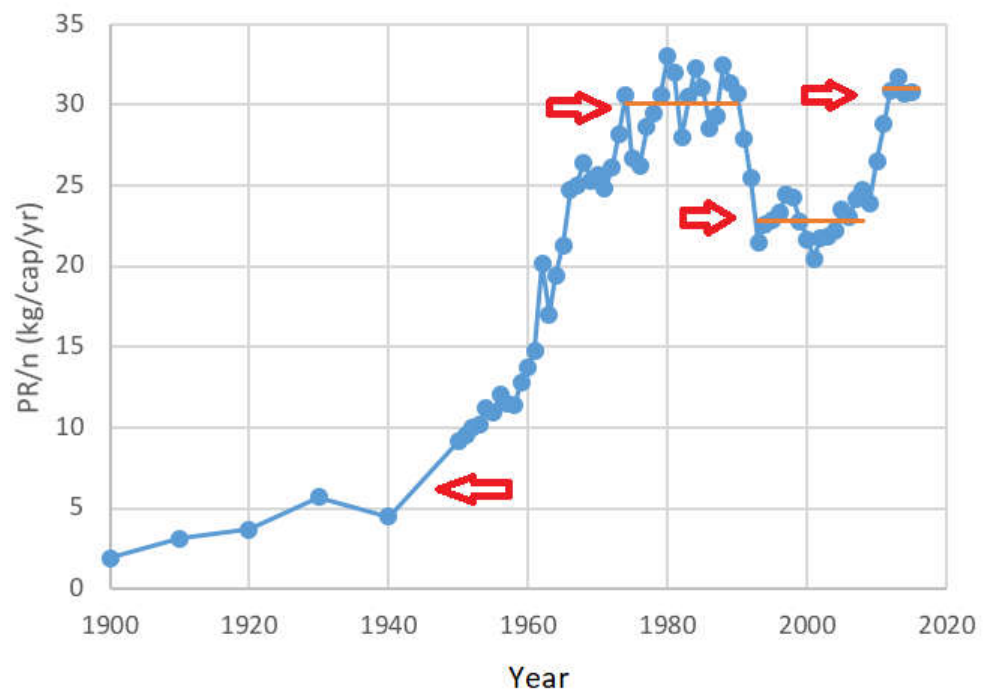

Figure 5. Historical trend for per capita phosphate rock production (based on [10]).

The world's population has been increasing approximately according to a linear trend for the last 50 years, adding between 70 and 87 million people per year onto the globe. Since 1997, the rate has been more stable, between 77 and 81 million people per year. Nevertheless, the UN estimates the annual population growth rate to decline steadily from this point forward. If the current level of per capita PR production rate is applied to the median UN population projection, the current reserves would last until the year 2315. However, if population growth rate continues to stay similar to the current rate (as forecasted in the UN "high" population estimate), they would only last until 2170.

There are reasons to be concerned about the short-term vulnerability of phosphorus supply, as well. Some of the major producers have an $\mathrm{R} / \mathrm{C}$ ratio of only a few decades (Table 1). Specifically, two of the top three producers, China and the US, have an R/C ratio of less than 30 years. Thus, both can be expected to be running low of $P$ in a similar time frame, when they will have to compete with each other for other sources, which are likely to include Morocco. Several investigators have looked at this situation on a country-by-country basis. Walan et al. [24] predicts that "exports will depend heavily on Morocco in the future." Cooper et al. [25] predicted that "70\% of global production is currently produced from reserves which will be depleted within 100 years," and that "Morocco, with nearly $77 \%$ of global reserves, will need to increase production by $700 \%$ by 2075 in order to meet most of this deficit." The situation looks dangerously similar to that in which the world found itself at the inception of the first oil crisis, with the difference that also China is now a major economic and military powerhouse.

The data indicate that a crisis in phosphorus resources is not yet imminent. Nevertheless, P scarcity, whether it occurs decades or in centuries from now, would be catastrophic for humanity. Although all future scenarios involve substantial assumptions, these could go either way: the catastrophe could be forestalled, or the situation could become even worse. This risk suggests that society should begin now to modify current wasteful practices concerning management of P resources, especially given that many of these practices result in environmental problems that affect us still today.

\section{Phosphorus Cycle}

Potential interventions to conserve known phosphorus resources require an understanding of the P flow through modern agricultural ecosystem. As $\mathrm{P}$ cannot be found in the atmosphere, due to the 
lack of stable gaseous forms, its cycle involves mainly transfer of this element between rocks, water, soil, sediments and organisms.

In the natural phosphorus cycle (Figure 6), rocks release phosphate ions and other minerals due to weathering, these are then distributed into soil and water. In soils, phosphate is absorbed by plants, and subsequently uptaken by animals consuming the latter. Through the process of animal excretion (and decomposition of dead animals and plants), phosphate returns to the soil. Natural terrestrial ecosystems tend to recycle phosphorus many times before it washes out of the local environment. For example, Leopold [26] reports that an atom of phosphorus can be cycled locally about 47 times before being lost. Even after finding its way to aquatic water bodies, phosphorus may recycle between the water column and sediments repeatedly.

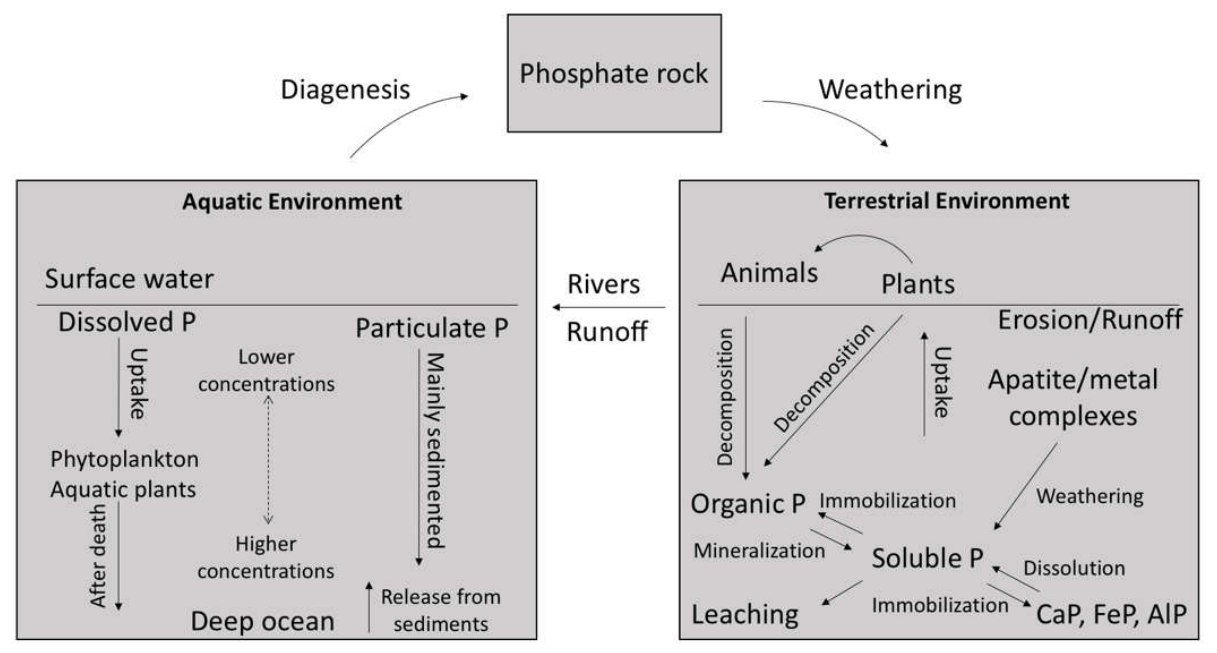

Figure 6. Natural phosphorus cycle in aquatic and terrestrial environments (based on $[27,28]$ ).

Eventually, phosphorus-containing substances flow to the ocean via rivers, estuaries and coastal waters. Other sources to the ocean include hydrothermal inputs and low-temperature reactions between sea waters and sea-floor. The phosphorus delivered into the oceans can be categorized in two forms; dissolved and particulate. Particulate phosphorus, due to high $\mathrm{pH}$ of seawater and its buffering property, is barely soluble and is found mostly sedimented on the bottom of the oceans and seas. Hence, it does not participate in the active phosphorus cycle until it is returned to the land by tectonic forces.

Dissolved phosphorus, once released into the oceans, is immediately absorbed by phytoplankton and aquatic plants, and therefore its concentration near the water surface is approximately zero. When phytoplankton and other organisms die, they sink transporting nutrients into deeper strata. Some may be sequestered in sediments, but a portion of them returns to the surface by upwelling currents along continental margins, where this phenomenon is favored by prevailing winds, creating as a consequence well-known fishery areas, such as those off the western coast of South America and North Africa. It also results in higher P concentrations in coastal sediments, which would, in geologic time, lead to the formation of new, high-concentration phosphate rock (the existing formations are approximately ten to hundred million years old). Sedimented oceanic phosphorus may form again deep phosphate rocks during the process of diagenesis. This process is significantly slow, with a time scale of the order $10^{8}-10^{9}$ years $[28,29]$ : based on these considerations, the phosphorus cycle can be considered one of the slowest biogeochemical cycles among all elements.

\section{Streamlining the Human P Cycle}

Humans intervene in the phosphorus cycle by many ways. The anthropogenic phosphorus cycle resembles the natural one (Figure 7), except it uses only the higher concentration mineral phosphorus 
deposits (phosphate rock) more intensively. The total anthropogenic flux of phosphorus is about three times the natural flux, that is about 29 against $10 \mathrm{Mt} / \mathrm{yr}$ [9] and, in this accelerated cycle, only a negligible fraction of the phosphorus is recycled. In addition, the anthropogenic cycle, mainly targeted to the production of food for human consumption, significantly "leaks" phosphorus along the way, resulting in the fact that only about $16 \%$ of the mined phosphorus is consumed by humans, in the end. The most significant leaks are erosion and leaching from cropland, improper disposal of animal waste, and production of food waste, all of which could have negative environmental impacts. Targeted efforts at reducing $\mathrm{P}$ wastage could therefore potentially increase the duration of existing reserves by a factor of about 8 .

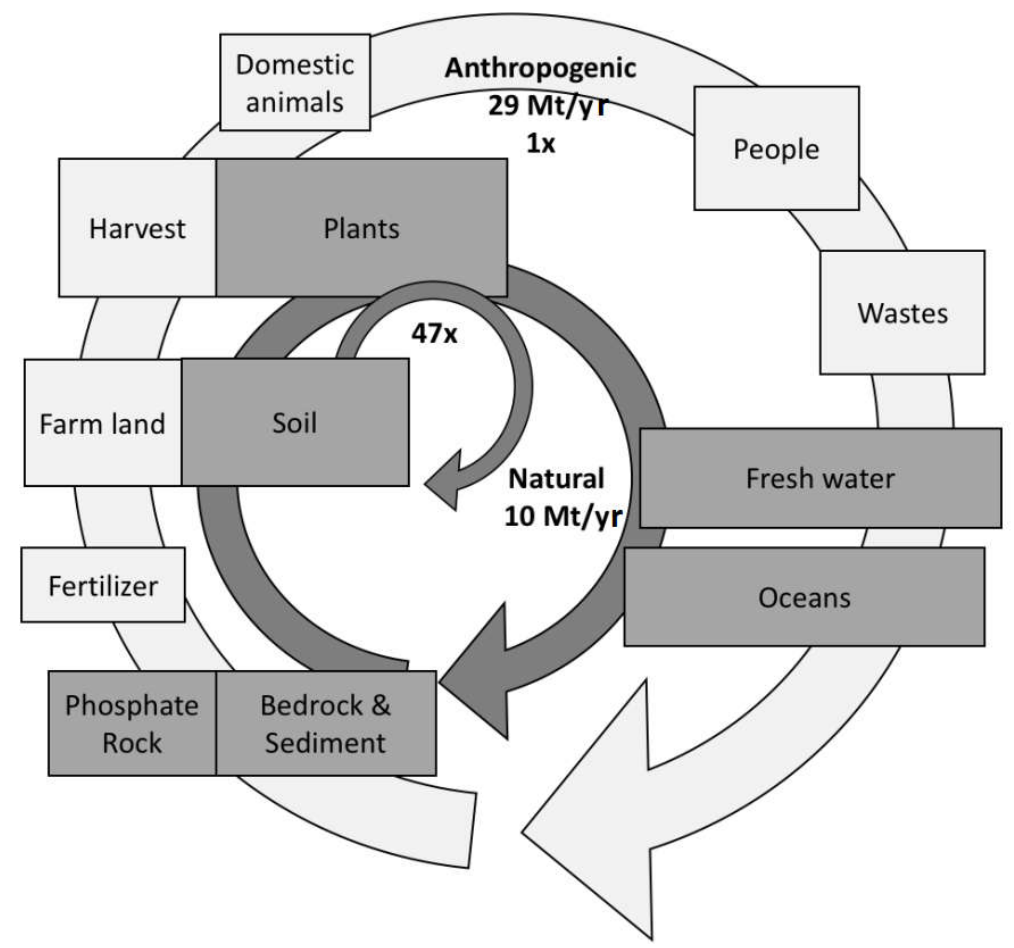

Figure 7. The natural and anthropogenic (agricultural) phosphorus cycles.

Reduction of food waste may have the potential to conserve significant amounts of phosphorus. Reducing losses from agricultural land could be equally important, but more difficult to achieve, as this is usually attempted by implementing voluntary Best Management Practices (BMPs), which are mainly aimed at the control of nutrients and pollutants (pesticides) leaching to surface waters. Losses via animal waste could be reduced either by reducing the incidence of meat consumption in human diet, or by more effectively recycling animal waste. Recycling could be applied at other parts of the cycle, such as from crop waste, harvest waste, food waste, and human waste.

Recycling of human wastes will be specifically discussed below. However, it should be understood that since only about 16\% [11] of mined phosphorus is actually consumed in the human diet, even if $100 \%$ recycling of human waste could be attained, this would only reduce our dependence on mined phosphorus by $16 \%$, as all the previous forms of environmental $\mathrm{P}$ leaching would not have been addressed. Nevertheless, even such a relatively small recovery and recycling of phosphorus could be an important intervention in the realm of global $\mathrm{P}$ consumption. Figure 8 shows the effect of human intervention on open phosphorus cycle (a) and how this cycle can be closed by applying phosphorus recovery processes for wastewater and sewage sludge (b). 
(a)

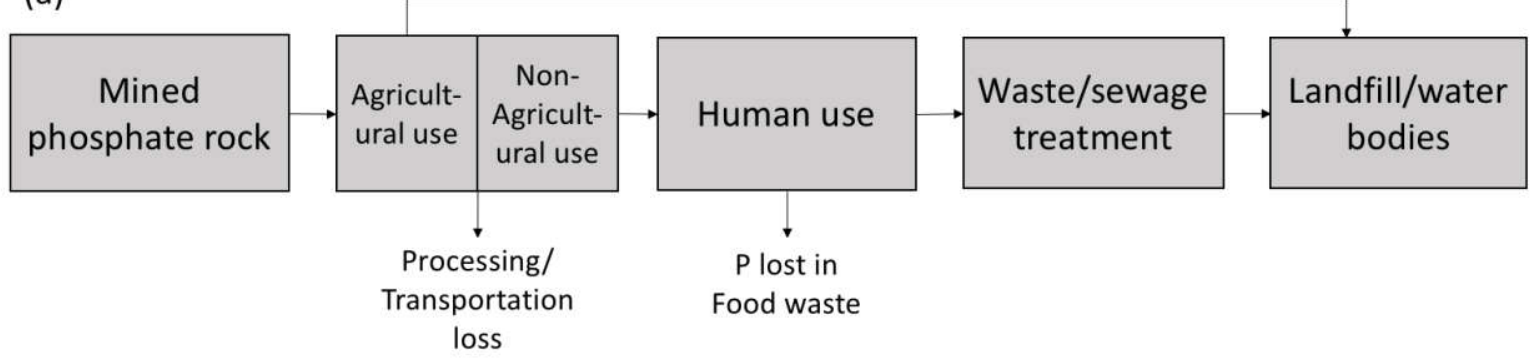

(b)

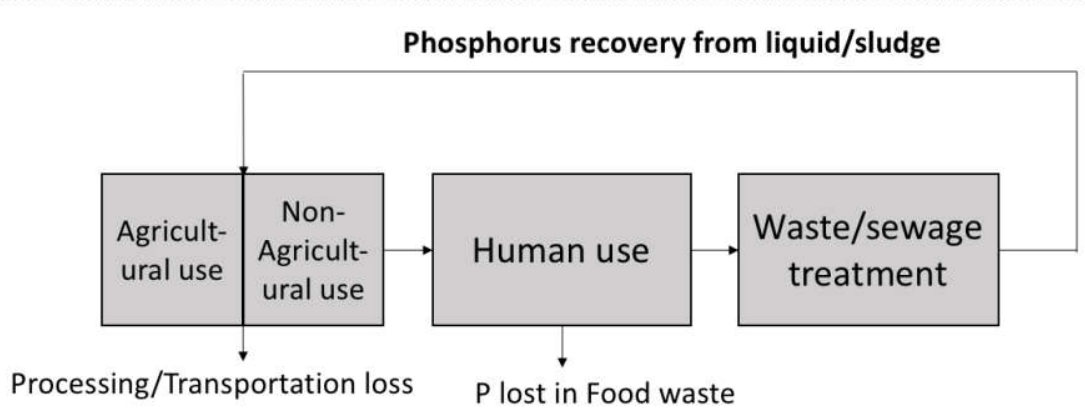

Figure 8. (a) Open phosphorus cycle, (b) Closed phosphorus cycle with recovery process (based on $[3,30])$.

\section{Environmental Effects of Phosphorus Pollution}

Mankind, breaking the natural phosphorus cycle, is releasing more phosphorus-containing wastes into the rivers and seas. The acceleration of natural cycle has already caused disastrous problems in aquatic and marine ecosystems, represented in primis by the eutrophication phenomenon.

In the presence of a high enough amount of phosphorus in surface waters, nitrogen will in fact temporarily become a limiting agent for aquatic plants and algae growth. In this case, nitrogen-fixing organisms such as bluegreen bacteria will start to overdevelop to bring back the system into an equilibrium with the increased amount of available P. Accumulated, internal water body loadings could maintain excessive phosphorus levels even after external pollution sources had been eliminated [31-33].

The produced, dead biomass often accumulates in the sediment of freshwater bodies, contributing in the long term to sediment oxygen demand, depleting oxygen content in the water column. In addition, large quantities of suspended photosynthetic biomass could cause large daily swings of dissolved oxygen (DO) and $\mathrm{pH}$ (linked to dissolved $\mathrm{CO}_{2}$ ). In marine environments subject to nutrient runoff from coastal lands, biomass may settle into deeper layers, resulting in fast oxygen depletion (hypoxia) and acidification due to dissolved $\mathrm{CO}_{2}$. All these effects are indicated under the term eutrophication, and are considered a water quality degradation (pollution) issue that can induce additional negative ecological impacts. For this reason, at present, much effort is being devoted to the removal of N \& P from wastewater discharges, especially in low exchange water bodies [34-36], as foreseen by current environmental protection regulations (in the EU, the Water Framework Directive, WFD). Such removal can occur both with physicochemical and biological processes $[37,38]$ however, is it costly and perhaps not completely necessary in view of the new paradigms on wastewater management, stressing resource recovery according to circular economy principles [39-41].

In most cases, this is due to excessively high concentration of phosphorus in water bodies. "Harmful algal bloom" may also produce toxic, or taste-and-odor compounds, in drinking water sources. 
Photosynthetic reactions remove carbonates from water. Potentially, alkalinity shifts to hydroxide form, raising the solution $\mathrm{pH}$. For example, water with alkalinity of $100 \mathrm{mg} / \mathrm{L} \mathrm{CaCO}_{3}$ would theoretically have a $\mathrm{pH}$ of 11.3 if all carbonates were removed. In real systems, this may be buffered to a certain degree due to exchange of $\mathrm{CO}_{2}$ with the atmosphere. During the night the opposite happens, as $\mathrm{CO}_{2}$ is generated by algal respiration, lowering the $\mathrm{pH}$. Such potentially significant $\mathrm{pH}$ swings could be detrimental to indigenous biota, and may cause leaching of heavy metals from the sediments. In addition, high $\mathrm{pH}$ would cause ammonium to convert to the ammonia form, more toxic to fish.

In oceans (as well as in deep, stratified lakes) photosynthesis and respiration reactions are to some extent spatially separated. Photosynthesis occurs within the surface water layers, where light can penetrate. Phytoplankton then sinks where its degradation consumes oxygen and reduces $\mathrm{pH}$. The low oxygen condition is known as hypoxia, and more popularly as "dead zone" if oxygen levels are low enough to stress or eliminate fisheries. Additionally, if deep waters are occasionally brought to the surface due to coastal upwelling, then the resulting low $\mathrm{pH}$ conditions can inhibit growth of organisms such as mollusks and crustaceans that form shells incorporating calcium carbonate.

\section{Phosphorus Removal}

The $\mathrm{P}$ issue is clearly a double-edged problem: it concerns both phosphorus potential resource depletion, and environmental pollution. As mentioned above, there are several interventions that could conserve phosphorus, reduce its discharge to the environment, or both. The focus henceforth should be on technologies and approaches allowing for recovery of phosphorus from wastewater and its byproducts.

Raw wastewater contains somewhere in the range of $4.0-16.0 \mathrm{mg}$ P/L. About $20-30 \%$ of this is removed during conventional biological aerobic treatment without any use of specific P-removal processes though anabolic uptake (i.e., the incorporation of $\mathrm{P}$ in new cellular material). This would leave a nominal 3.0 to $12.0 \mathrm{mg} \mathrm{P} / \mathrm{L}$ in treated effluents. However, due to recent environmental regulations, this removal rate is often not sufficient. Based on the European Water Framework Directive [42], P concentrations released in the environment from wastewater treatment facilities located in sensitive areas (i.e., those where discharge of excessive nutrients could originate severe basinwise water quality impairments-including eutrophication) have been identified as $1 \mathrm{or} 2 \mathrm{mg} / \mathrm{L}$ depending on the facility's capacity.

The first phosphorus removal processes date back to the late 1950s when companies started to achieve this goal by using the only known method, chemical precipitation, which is still used substantially today. In chemical precipitation, $\mathrm{P}$ is removed by adding chemicals such as iron, aluminum or calcium salts to the wastewater. The salts precipitate as insoluble hydroxides, phosphorus is removed by a combination of co-precipitation and adsorption to the metal hydroxides. If combined with filtration, chemical methods can achieve effluent concentrations as low as about $0.05 \mathrm{mg} \mathrm{P} / \mathrm{L}$ [43]; however, the precipitated $\mathrm{P}$ is bound in a sludge that necessitates of complex and expensive operations to make it recoverable and reusable.

From the mid-1960s researchers discovered that under certain conditions activated sludge can absorb phosphorus in excess of their needs [44]. Biological phosphorus removal was discovered and gradually introduced into common practice. If the wastewater contains a sufficient quantity of readily biodegradable organic matter, fermentation in an anaerobic zone produces volatile fatty acids (VFAs). A specific group of bacteria known as polyphosphate accumulating organisms (PAOs) uses the energy stored in intracellular polyphosphates to take up VFAs and convert them into intracellular organic storage compounds called polyhydroxyalkanoates (PHAs). Intracellular polyphosphates release orthophosphate (OP) into the mixed liquor, and P concentration increases within. An aerated zone downstream contains sufficient oxygen for the organisms to use PHAs for its energy requirements; at this point, PAOs take advantage of this 'substrate bounty' condition to regenerate their stores of polyphosphate, removing OP from solution in excess of actual requirements (this is in fact called excess, or 'luxury' uptake). Phosphorus in solution falls to low levels, below 1.0 mg P/L [44]. The organisms 
are then separated from the effluent and returned to the anaerobic zone, and the low-P solution is released as effluent. Biological phosphorus removal can consistently achieve nowadays, with properly managed processes, 75 to $93 \%$ reduction of effluent phosphorus.

Although biological processes may not remove $P$ to levels as low as chemical processes, they have some advantages: there is no need of chemicals, the amount of sludge produced is lower than for chemical precipitation, and the biosolids that are produced are easier to utilize than chemical sludge.

These phosphorus-contained sludges were, and sometimes still are, transferred to landfills; however, this is forbidden by current legislation Europe-wide. Given the discussion in this paper, it would seem reasonable to modify processing technologies and direct these sludges to a recovery of phosphorus (and energy) in the form of products such as struvite $\left(\mathrm{NH}_{4} \mathrm{MgPO}_{4} \cdot 6 \mathrm{H}_{2} \mathrm{O}\right)$, a mineral which can be utilized for fertilizer production.

\section{Phosphorus Recovery}

The most important difference between phosphorus removal and phosphorus recovery processes is that the former aims at obtaining phosphorus-free effluents from wastewater treatment plants (WWTPs), while the latter is focusing on phosphorus-containing by-products, which can then be reused for another purpose.

Phosphorus recovery technologies are mainly applied to industrial and urban wastewater, while there are few methods available for the livestock manure due to lack of suitable markets for processed manure, and the ready availability of low-cost alternatives (e.g., disposal) [45]. In the first case, recovery of phosphorus can be implemented in different stages of treatment, from the liquid to the sludge phase, and also from sludge post-treatment, such as incinerated sludge ash. Recovery rate from a liquid phase can reach up to a maximum of $40-50 \%$, while in the sludge phase higher recovery rates of close to $90 \%$ can be achieved [46]. Figure 8 shows different possible locations for phosphorus recovery processes within a wastewater treatment plant. Table 2 shows a classification of commercially available technologies organized by type of waste treated and by type of technology.

As accumulated polyphosphates accumulated in bacterial cells performing an enhanced biological phosphorus removal (EBPR) process can be released under anaerobic conditions, phosphorus can be recovered in a relatively efficient way from the supernatant of the side-stream recycled to the activated sludge process, the effluent after secondary sedimentation, or from the dewatering process after anaerobic digestion of sludge (location L1, L2, L3 in Figure 9). Recovery of phosphorus from wastewater streams is commonly achieved by precipitation/crystallization processes. Typically, the product of this process is in the form of calcium phosphate or magnesium ammonium phosphate hexahydrate (struvite), the latter a suitable mineral for fertilizer use. Struvite crystallization is one of the current leading technologies for P recovery, described in detail below. Recovery from the solid phase can also be achieved from the primary sludge, excess sludge after secondary sedimentation, the raw sludge before anaerobic digestion and the sludge before and after dewatering (locations S1-S5 in Figure 9). Crystals of struvite and calcium phosphate may also be obtained from sewage sludge or sludge ash with alternative processes: as an example, it is possible to recover $\mathrm{P}$ from sludge ash after incineration (location A in Figure 9), and this is actually the technology in which the most concentrated form of phosphorus will be obtained; $4-11 \%$ by weight comparable to phosphate rock with about $13 \%$ phosphorus content [47-49]. Phosphorus can be recovered from ashes by acid extraction or bioleaching. The phosphorus in the sludge ash can also be recovered in a fairly pure form as phosphoric acid or as white phosphorus using high-temperature thermal treatment processes [49]. 
Table 2. Known processes for phosphorus recovery from wastewater and sewage sludge (based on [50]).

\begin{tabular}{|c|c|c|c|c|}
\hline Sludge Type & Process Name & Method & Products & Operational Scale \\
\hline \multirow[t]{6}{*}{ Sludge liquor } & P-ROC & Adsorption & $\mathrm{CaP}, \mathrm{CaP}$ on $\mathrm{CSH}$ & Semi-industrial \\
\hline & RECYPHOS & Adsorption & $\mathrm{FeP}$ & Semi-industrial \\
\hline & PHOSIEDI & Adsorption & $\mathrm{CaP}$ & Lab scale \\
\hline & PHOSTRIP & Precipitation & $\mathrm{CaP}$ & Full scale \\
\hline & PRISA & Precipitation & Struvite & Semi-industrial \\
\hline & CRYSTALACTOR & Pellets & $\mathrm{CaP}$, struvite & Full scale \\
\hline \multirow{8}{*}{ Digested sludge } & FIX-PHOS & Without leaching & $\mathrm{CaP}$ on $\mathrm{CSH}$ & Lab scale \\
\hline & SEABORNE & With leaching & Struvite & Full scale \\
\hline & STUTTGARTER VERFAHREN & With leaching & Struvite & Full scale \\
\hline & LOPROX/PHOXAN & With leaching & Phosphoric acid & Full scale \\
\hline & CAMBI & With leaching & $\mathrm{FeP}, \mathrm{AlP}, \mathrm{CaP}$ & Lab scale/Full scale \\
\hline & AQUA RECI & With leaching & $\mathrm{FeP}, \mathrm{AlP}, \mathrm{CaP}$ & Lab scale/Full scale \\
\hline & BIOLEACHING & With leaching & Struvite & Lab scale \\
\hline & $\mathrm{BIO} \mathrm{CON}$ & With leaching & Phosphoric acid & Semi-industrial \\
\hline \multirow[t]{4}{*}{ Sludge ash } & MEPHREC & Thermal treatment & $\mathrm{CaP}$ & Semi-industrial \\
\hline & ASH DEC & Thermal treatment & Fertilizer & Semi-industrial \\
\hline & THERMPHOS & Thermal treatment & Elemental phosphorus & Industrial process \\
\hline & PHOSPHORUS INDUSTRY & Thermal treatment & Fertilizer & Industrial process \\
\hline
\end{tabular}

Primary sedimentation

Secondary sedimentation

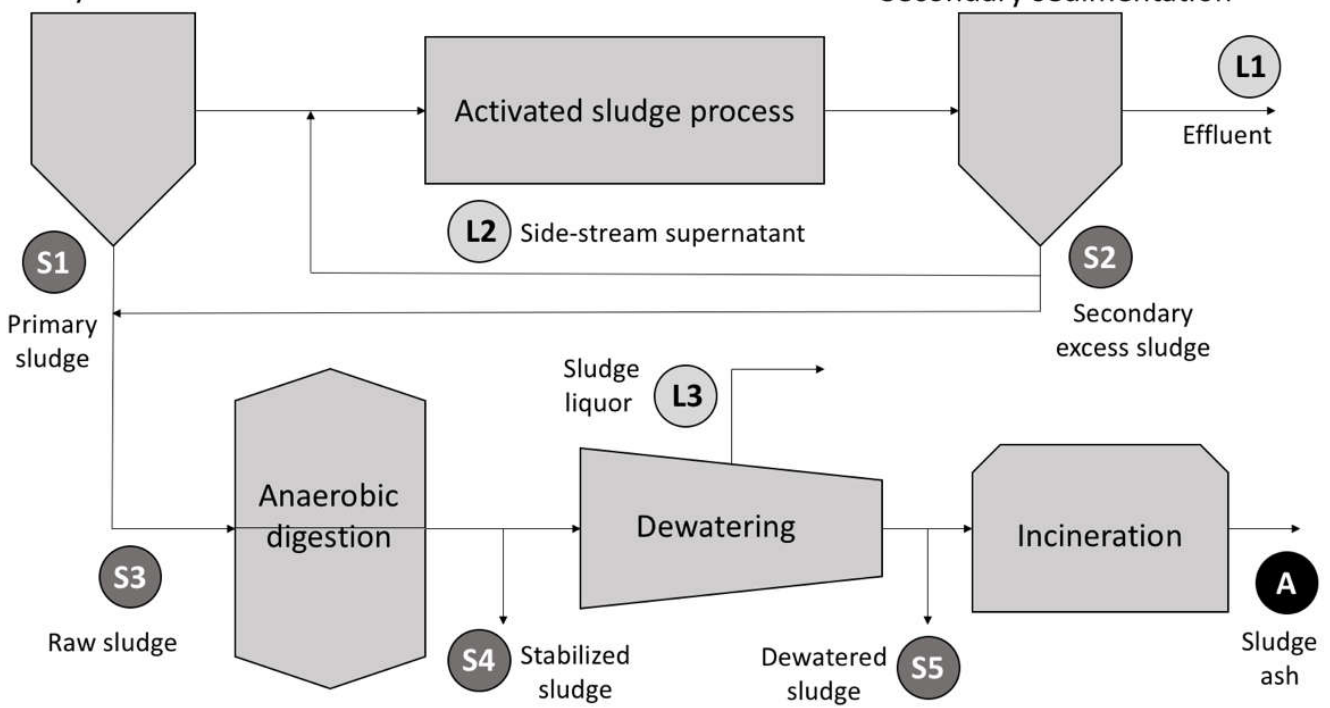

Figure 9. Possible phosphorus recovery locations in a conventional WWTP (based on $[30,46])$.

\subsection{Struvite Crystallization}

Magnesium ammonium phosphate hexahydrate $\left(\mathrm{MgNH}_{4} \mathrm{PO}_{4} \cdot 6 \mathrm{H}_{2} \mathrm{O}\right)$, or struvite, is a white mineral that can be naturally formed under certain conditions in sewer systems and WWTP conduits. In WWTPs it is often considered a nuisance, due to its potential for uncontrolled precipitation in undesired locations, such as in pipes, where it could form severe clogging [51]. This occurs typically in those parts of a WWTP where there is localized turbulence, for instance in pumps, aerators and pipes, due to pressure decrease and consequent release of dissolved $\mathrm{CO}_{2}$. This will increase $\mathrm{pH}$ levels and, consequently, enhance chances of its formation [52]. Removal of struvite incrustations under these circumstances is quite expensive. Incidentally, it should be noted that Struvite also precipitates 
in alkaline urine, forming one type of the kidney stones that may affect about $15 \%$ of the human population at one point in each individuals' life.

Struvite, however, can also be formed under controlled conditions in crystallization reactors, in which it is removed as small, fairly pure pellets. Low solubility, low metal content and the presence of both nitrogen and magnesium, which are also basic nutrient elements, make struvite suitable as a slow-release fertilizer.

The process of struvite crystallization is based on the following stoichiometric equations:

$$
\begin{aligned}
& \mathrm{Mg}^{2+}+\mathrm{NH}_{4}{ }^{+}+\mathrm{PO}_{4}{ }^{3-}+6 \mathrm{H}_{2} \mathrm{O} \rightarrow \mathrm{MgNH}_{4} \mathrm{PO}_{4} \cdot 6 \mathrm{H}_{2} \mathrm{O} \\
& \mathrm{Mg}^{2+}+\mathrm{NH}_{4}{ }^{+}+\mathrm{HPO}_{4}{ }^{2-}+6 \mathrm{H}_{2} \mathrm{O} \rightarrow \mathrm{MgNH}_{4} \mathrm{PO}_{4} \cdot 6 \mathrm{H}_{2} \mathrm{O}+\mathrm{H}^{+} \\
& \mathrm{Mg}^{2+}+\mathrm{NH}_{4}{ }^{+}+\mathrm{H}_{2} \mathrm{PO}_{4}{ }^{-}+6 \mathrm{H}_{2} \mathrm{O} \rightarrow \mathrm{MgNH}_{4} \mathrm{PO}_{4} \cdot 6 \mathrm{H}_{2} \mathrm{O}+2 \mathrm{H}^{+}
\end{aligned}
$$

In the $\mathrm{pH}$ range of struvite precipitation ( $\mathrm{pH} 7-11$ ) the reaction of $\mathrm{HPO}_{4}{ }^{2-}$ is the dominant one [53]. Key factors in struvite formation are $\mathrm{pH}$, magnesium concentration and presence of other competing ions, such as calcium, in the original solution. In most cases, the limiting agent in wastewater streams is magnesium, therefore it should be added to the process in the form of $\mathrm{MgCl}_{2}, \mathrm{Mg}(\mathrm{OH})_{2}$ or $\mathrm{MgO}$ to ensure its stoichiometric concentration. In addition to stoichiometry, an appropriate level of $\mathrm{pH}$ needs to be verified and, for this, addition of sodium hydroxide to the solution is the most common approach. Using added $\mathrm{MgO}$ or $\mathrm{Mg}(\mathrm{OH})_{2}$ as a source of magnesium could also provide sufficient $\mathrm{pH}$ adjustment to the solution (due to the oxides' alkalinity) but their low level of solubility should also be considered as a drawback. The final product obtained, struvite, can be further used directly as a fertilizer (if it meets the requirements as certified fertilizer, based on EU criteria), otherwise it can be further processed by the fertilizer industry to overcome such limitations.

Struvite solubility product is in the range of 9.4-13.26 [54] and it can be precipitated within $\mathrm{pH}$ range 7-11 [53]. Increase in $\mathrm{pH}$ will decrease struvite solubility and hence enhance its precipitation potential [53]. One of the key obstacles on the way of precipitation is the presence of other competitive ions, particularly calcium $\left(\mathrm{Ca}^{2+}\right)$. This can lead to impurities in the final precipitate in the form of calcium phosphate salts. Studies suggest that in order to achieve effective precipitation the $\mathrm{Ca}^{2+}: \mathrm{Mg}^{2+}$ ratio should be $<1$ [55] unless there is abundant concentration of ammonium in solution [56]. Many studies have been conducted on the effect of calcium co-precipitation on the process efficiency [55,57-59].

One of the advantages of struvite crystallization is that it can simultaneously remove phosphorus and nitrogen, in fact, tis mineral typically contains $12 \% \mathrm{P}$ and $5 \% \mathrm{~N}$, by mass. A high efficiency of $80-90 \%$ can be achieved for soluble phosphorus recovery in the process. Struvite crystallization is mainly effective for waste streams with low solids content and relatively high phosphorus concentration $\left(\mathrm{P}_{-} \mathrm{PO}_{4}>50 \mathrm{mg} / \mathrm{L}\right)$. The hydraulic retention time of the process is usually less than $60 \mathrm{~min}$, but high solid retention times (usually more than 10 days) are needed to allow sufficient crystal growth to achieve larger, well separated stones.

The crystallization process performance can be improved by introducing seed materials to the system $[60,61]$. The presence of seed materials improves crystals reaction rate and reduces reaction time. They also improve the nucleation process (crystal birth) of struvite if having sufficiently large surface area [60]. Struvite itself has been studied for application as a seed material, in order to improve the efficiency of the crystallization process $[60,62,63]$. Shih et al. [64] showed that under optimal operational conditions (e.g., $\mathrm{pH}$ and constituent ion molar ratios) and with proper dosage and size of seed material, up to $95.8 \%$ P recovery could be achieved. Nevertheless, using seed material may have its own drawbacks: implementation costs, phosphate ion selectivity, efficient settling, and separation are some of the challenges to overcome [60]. 


\subsection{P Recovery by Assimilation}

Adsorption and assimilation of phosphate by algae is another promising method for P- recovery from wastewater [65-67]. Photosynthetic algae use $\mathrm{CO}_{2}$ and nutrients $\left(\mathrm{NH}_{4}{ }^{+}, \mathrm{NO}_{3}{ }^{-}\right.$and $\left.\mathrm{PO}_{4}{ }^{3-}\right)$ for their growth, while producing oxygen. This is then utilized by heterotrophic bacteria for their metabolism thus producing $\mathrm{NH}_{4}{ }^{+}, \mathrm{NO}_{3}{ }^{-}$and $\mathrm{PO}_{4}{ }^{3-}$ [60]. Algae have been applied in the aerobic ponds of wastewater treatment plants to deal with organic carbon and pathogenic pollutants removal [67-69]; however, their phosphorus removal was generally low [70], the main reason being that aerobic ponds are not optimized for biomass production [67]. Algal assimilation, nonetheless, could have a great potential for P-uptake under optimized conditions, as algal dry biomass can contain up to $3.3 \% \mathrm{P}$ by weight [71]. El Hamouri [72] reported 63\% P-removal by an algal pond. Light intensity, influent $\mathrm{P}$ concentration, $\mathrm{pH}$, aeration, mixing rate and temperature are important factors for achieving high $\mathrm{P}$ recovery by algal biomass [60-67]. Microalgae are most widely used in these wastewater treatment systems. Harvesting of algae at the end of the treatment could be achieved by filtration, sedimentation or centrifugation: although, there are some successful examples of algae harvesting at the pilot scale, large-scale application of such systems is still challenging [60-69].

The big advantage of $\mathrm{P}$ recovery by algal assimilation is the value of the produced biomass. The harvested algal biomass can be used in different industries including slow-release fertilizers, animal food production, pharmaceuticals, food processing, etc. and can be a feedstock for liquid biofuels production, due to high lipids content [73].

\subsection{Membrane Technologies}

Phosphorus recovery using membrane technologies is relatively new, and still in a development phase. Membrane media have great potential in increasing concentrations of constituent ions in a solution for further precipitation of (for example) struvite and calcium phosphate compounds [60]. Reverse osmosis (RO), forward osmosis (FO), microfiltration (MF), ultrafiltration (UF), nanofiltration (NF) and possibly a combination thereof could be used for simultaneous wastewater treatment and nutrient recovery. Generally, membrane technologies allow to obtain concentrated streams that could be subsequently subjected to a precipitation process for $\mathrm{P}$ recovery. $\mathrm{Mg}^{2+}$ and $\mathrm{Ca}^{2+}$ sources and $\mathrm{pH}$ adjustment methods would be required to achieve the initial conditions for the precipitation process, while the performance of these systems could be affected by several parameters. Influent quality, hydraulic load, salinity, membrane fouling (organic, inorganic, or biological fouling) are the most important ones $[60,74]$.

Osmotic membrane bioreactors (OMBRs) are a novel approach for P recovery using membrane technologies $[75,76]$. The process is an integration of osmotically-driven membranes and biological treatment, which has been used recently for phosphorus recovery mainly in the form of amorphous calcium phosphate $\left(\mathrm{ACP}, \mathrm{Ca}_{3}\left(\mathrm{PO}_{4}\right)_{2} \cdot \times \mathrm{H}_{2} \mathrm{O}\right)$ [75]. OMBR uses a non-porous osmotically-driven membrane instead of conventional porous MF or UF membranes under hydraulic pressure driving force [74,77]: the use of osmotically-driven membranes, such as FO membranes, has the advantage of an enhanced rejection, reduced fouling and lower costs [60,74].

Qiu and Ting [75] showed that $>95 \%$ P could be recovered through this system. The system's performance, however, can be highly affected by salinity $[75,78]$ and it has to be taken into consideration to achieve high efficiency. Integration of MF with FOMBR was studied by Qiu et al. [79], achieving $>90 \%$ P recovery. Luo et al. [80] investigated an OMBR-RO system in combination with an MF for recovering $\mathrm{P}$ in the form of Ca-P compounds, obtaining 15-20 wt \% P-containing precipitates. Ninety percent $\mathrm{P}$ recovery was achieved by Thing et al. [81] using a NF system and Hou et al. [82] obtained a remarkable $99 \%$ recovery by application of a NF and FO combination.

In spite of having demonstrated great efficiency and high $P$ recovery rates, membrane systems have been developed solely at the laboratory scale. The feasibility of continuous operation of these membranes is still a challenge [60], since membrane performance will significantly decrease with deposit accumulation (fouling), requiring frequent cleaning and showing gradual loss of performance. 
High operational costs for the overall process (cleaning, maintenance and chemicals for precipitation) are still high, which make membrane technologies difficult to implement at large scale at the moment $[60,74,76]$.

\section{Considerations on the Energy-Nutrient Nexus in WWTPs}

Wastewater treatment plants are essential facilities for the protection of the environment and public health; however, they are among the greatest public consumers of energy and resources in developed countries. It is in fact estimated that WWTPs are the single, most energy-intensive public operation in most towns of the developed world; up to 3-4\% of the total electric consumption in the US has been related to the water cycle, including WWTPs [83]. In Australia, where most treatment plants are based on conventional activated sludge process, including aerobic sludge digestion with no energy recovery (no onsite biogas production), electric energy use for running these systems may total $80 \mathrm{kWh} /$ capita-year [84]. In Europe, estimated optimized energy requirements (under current mainstream technology) are in the range $25-30 \mathrm{kWh} /$ capita-year [85]. In addition, WWTPs also need large amounts of process materials (chemicals) during their lifespan. Recovery of materials and energy with appropriate technologies could therefore be a desirable, additional requirement for future, sustainable WWTPs. By recovering N \& P contained in wastewater, an equivalent amount of external fossil-fuel energy, which would be required for the production of equal amounts of fertilizing elements $\mathrm{N}$ and $\mathrm{P}$ by industrial processes, would effectively be saved, corresponding to $19.3 \mathrm{kWh} / \mathrm{kg}$ $\mathrm{N}$ (extracted by the Haber-Bosch process), and $2.11 \mathrm{kWh} / \mathrm{kg} P$ (processed from PR) [86]. Hence, supposing that just $50 \%$ of all human-consumed $\mathrm{P}$ worldwide (3.84 Mt P/year, excluding upflow losses) could be usefully recovered $(1.92 \mathrm{Mt} \mathrm{P} / \mathrm{yr})$, this would translate both into direct recovery of an equal amount of limited P resources, and in the avoided consumption of about $4000 \mathrm{GWh}$ of energy, roughly the same consumed in 1 month in the entire Switzerland.

Therefore, from a sustainability point of view, it is not enough to summarize the aim of a WWTP referring solely to nutrients recovery. Minimum energy consumption is of significant importance in order to meet sustainable development objectives. One of the possible approaches is to improve the efficiency of plants by implementing adequate control systems, replacing old inefficient equipment and performing energy conservation analyses of plants [87]. Mathematical models are of great interest for optimization of current systems $[88,89]$ which can be a helpful tool for reducing energy consumption and maximizing resource recovery (in particular $\mathrm{N}$ and $\mathrm{P}$ ). A good example of such approach can be found in Vaneeckhaute et al. [90] that developed a generic nutrient model in order to optimize nutrient $(\mathrm{N}, \mathrm{P})$ and energy recovery of treatment facilities with a focus on fertilizer quality and quantity. Batstone et al. [91] showed that there is a serious need of improvement on current physicochemical models for them to be applied for nutrients recovery purposes.

More progress was achieved in the last decade; however, in terms of on-site energy generation in WWTPs. On-site generation is the most favorable approach in order to move towards WWTP sustainability as the generated energy can be directly used by the plant itself, and by other facilities as well [92-94].

Bio-electrochemical systems (BES) including microbial fuel cells (MFC) and microbial electrolysis cells (MEC) are relatively new approaches for on-site energy generation and nutrients recovery. These have been investigated since approximately a decade; however, applications are limited to pilot scale due to high capital costs and technological limitations. Studies on nutrient recovery using BESs have been mostly focused on removal of nitrogen, with few studies on their potential for phosphorus recovery. The latter show, nevertheless, great prospects on the P recovery issue [95]. MFC systems that directly convert the chemical energy of the wastewater into electricity by means of microorganisms through the conventional oxidation/reduction process have been tested, with no or limited large scale applications $[96,97]$. MEC systems, on the contrary, could generate methane or hydrogen by applying an electric current to the organic materials. Power generation by MFC systems are typically between 10 to $100 \mathrm{~mW} / \mathrm{m}^{2}$ [98,99]. Hydrogen recovery using MEC systems has not been studied thoroughly 
and consequently there are no practical application for that so far. In spite of problems and challenges of MFC and MEC systems application at the full-scale for on-site energy generation, they have shown potential of being beneficial. Sewage treatment using MFC systems in European Union could save up to $1 \mathrm{M}$ tonne/year, and a considerable amount of sludge disposal costs $[100,101]$. Bio-electrochemical systems could also be implemented for the integration of energy and nutrients recovery: there have been, in fact, interesting studies on the possibility of phosphorus recovery in the form of struvite by MFC systems [91,102]. Studies suggest that phosphorus could be removed up to $82 \%$ by MFC systems, $40 \%$ of which it could be recovered as struvite [103]. Fischer et al. [102] used a three-stage single chamber MFC for phosphorus recovery, achieving 78\% recovery in the form of struvite. MECs have also been used to that end: with a single-chamber MEC Cusick and Logan [104] were able to produce struvite at a rate of $0.3-0.9 \mathrm{~g} / \mathrm{m}^{2}$-hour. You et al. [105] investigated a two chamber MEC to achieve $97 \%$ phosphorus recovery by struvite precipitation. Despite the good results obtained by these systems on treatment efficiency; however, their main remaining drawback is the high capital cost per unit of energy produced $[60,106]$.

\section{Conclusions}

Although phosphorus resources are apparently abundant, they are not unlimited by any means. It can be reasonably anticipated that future generations may at some point find these resources to reflect a much more critical situation than the one currently perceived. It is clear that current agricultural practices waste a large amount of these resources, since only $16 \%$ of the total are effective for their planned use. Not only this is critical towards long-term sustainability of this element, but these wasteful practices also result in high levels of pollution that harm water supplies, fisheries and ecosystems balance even today. Taken together, these concerns should produce a strong moral and economic incentive to conserve phosphorus. Recovery from wastewater streams is one approach that could contribute to the improvement of current practices. Some proposed technologies were illustrated in the paper; notwithstanding the current limitations of some of them, it could be expected that they may, in a few years, reach a level of industrial maturity for full-scale application.

Author Contributions: All Authors discussed, conceived and designed the manuscript outline; S.D. analyzed literature data; D.V. contributed to the identification of analysis tools; A.G.C., A.C. and S.D. finalized the main body of the paper. All Authors contributed to its final version.

Acknowledgments: The work for this paper has been completed as a preparation for experimental activities under a project grant from Fondazione CARIPLO (Milan, Italy) to the University of Pavia. Mr. Daneshgar received full Ph.D. Scholarship support from the grant and Vaccari received travel support for visiting the LABTA2 Laboratory at the University of Pavia during summer semesters under the same grant.

Conflicts of Interest: The authors declare no conflict of interest. The founding sponsors had no role in the design of the study; in the collection, analyses, or interpretation of data; in the writing of the manuscript, and in the decision to publish the results.

\section{References}

1. Pfitzner, A.; Bräu, M.F.; Zweck, J.; Brunklaus, G.; Eckert, H. Phosphorus Nanorods-Two allotropic modifications of a long-known element. Angew. Chem. Int. Ed. 2004, 43, 4228-4231. [CrossRef] [PubMed]

2. Boskey, A. Bone composition: Relationship to bone fragility and antiosteoporotic drug effects. BoneKey Rep. 2013, 2, 447. [CrossRef] [PubMed]

3. Childers, D.L.; Corman, J.; Edwards, M.; Elser, J.J. Sustainability Challenges of Phosphorus and Food: Solutions from Closing the Human Phosphorus Cycle. Bioscience 2011, 61, 117-124. [CrossRef]

4. Pasek, M.A.; Sampson, J.M.; Atlas, Z. Redox chemistry in the phosphorus biogeochemical cycle. PNAS 2014, 111, 15468-15473. [CrossRef] [PubMed]

5. Glindemann, D.; Edwards, M.; Liu, J.; Kuschk, P. Phosphine in soils, sludges, biogases and atmospheric implications-A review. Ecol. Eng. 2005, 24, 457-463. [CrossRef]

6. Filippelli, G.M. Phosphate rock formation and marine phosphorus geochemistry: The deep time perspective. Chemosphere 2011, 84, 759-766. [CrossRef] [PubMed] 
7. Sheldon, R.P. Industrial Minerals-With Emphasis on Phosphate Rock. In Resources and World Development; McLaren, D.J., Skinner, B.J., Eds.; John Wiley \& Sons Ltd.: New York, NY, USA, 1987; pp. 347-361.

8. IFA. International Fertilizer Association Production and International Trade Report. 2016. Available online: https: / / fertilizer.org/Statistics (accessed on 20 March 2017).

9. Smil, V. Phosphorus: Global Transfers, Causes and consequences of global environmental change. In Encyclopedia of Global Environmental Change; Douglas, I., Munn, T., Eds.; John Wiley \& Sons, Ltd.: Chichester, UK, 2002; Volume 3, pp. 536-542. ISBN 0-471-97796-9.

10. Vaccari, D.A. How do you spot a trend? An examination of recent phosphate rock production. In the special issue on Sustainable Phosphorus. Glob. Environ. Res. 2015, 19, 3-8.

11. Jasinski, S.M. Phosphate Rock, USGS Mineral Commodities Summary. Available online: http://minerals. usgs.gov/minerals/pubs/commodity/phosphate_rock/ (accessed on 15 March 2017).

12. Notholt, A.J.G.; Sheldon, R.P.; Davidson, D.F. Phosphate Deposits of the World. Volume 2: Phosphate Rock Resources; Cambridge University Press: Cambridge, UK, 1989.

13. Cordell, D.; Drangert, J.O.; White, S. The story of phosphorus: Global food security and food for thought. Glob. Environ. Chang. 2009, 19, 292-305. [CrossRef]

14. De Ridder, M.; de Jong, S.; Polchar, J.; Lingermann, S. Risks and Opportunities in the Global Phosphate Rock Market; The Hague Centre for Strategic Studies (HCSS): The Hague, The Netherlands, 2012.

15. Vaccari, D.A. Phosphorus: A Looming Crisis. Sci. Am. 2009, 300, 54-59. [CrossRef] [PubMed]

16. Van Kauwenbergh, S.J. World Phosphate Rock Reserves and Resources; International Fertilizer Development Center: Muscle Shoals, AL, USA, 2010; ISBN 978-9-88999-167-3.

17. Edixhoven, J.D.; Gupta, J.; Savenije, H.H.G. Recent revisions of phosphate rock reserves and resources: Reassuring or misleading? An in-depth literature review of global estimates of phosphate rock reserves and resources. Earth Syst. Dyn. 2013, 4, 1005-1034. [CrossRef]

18. Gharbi, A. Les Phosphates Marocains, Chronique de la Recherche Minière; Bureau de Récherches Géologiques et Minières: Orléans, France, 1998; pp. 531-532.

19. Terrab, M. IMPHOS Annual Report; World Phosphate Institute: Casablanca, Morocco, 2006.

20. Cordell, D.; White, S.; Lindström, T. Peak phosphorus: The crunch time for humanity? The Sustainability Review. 2011. Available online: http:/ / www.thesustainabilityreview.org/articles/peak-phosphorus-thecrunch-time-for-humanity (accessed on 20 April 2017).

21. Mew, M. Future Phosphate Rock Production-Peak or Plateau? Fertecon Research Centre Limited-A Matter of Opinion. 2011. Available online: http:/ / www.fertecon-frc.info/page15.htm (accessed on 1 October 2012).

22. Vaccari, D.A.; Strigul, N. Extrapolating phosphorus production to estimate resource reserves. Chemosphere 2011, 84, 792-797. [CrossRef] [PubMed]

23. Scholz, R.W.; Wellmer, F.W. Approaching a dynamic view on the availability of mineral resources: What we may learn from the case of phosphorus? Glob. Environ. Chang. 2013, 23, 11-27. [CrossRef]

24. Walan, P.; Davidsson, S.; Johansson, S.; Höök, M. Phosphate rock production and depletion: Regional disaggregated modeling and global implications. Resour. Conserv. Recycl. 2014, 93, 178-187. [CrossRef]

25. Cooper, J.; Lombardi, R.; Boardman, D.; Carliell-Marquet, C. The future distribution and production of global phosphate rock reserves. Resour. Conserv. Recycl. 2011, 57, 78-86. [CrossRef]

26. Leopold, A. A Sand County Almanac and Sketches Here and There; Oxford University Press: New York, NY, USA, 1943; ISBN 978-0-19-500777-0.

27. Filippelli, G.M. The Global Phosphorus Cycle: Past, Present, and Future. Elements 2013, 4, 89-95. [CrossRef]

28. Pierrou, U. The Global Phosphorus Cycle. Ecol. Bull. Nitrogen Phosphorus Sulphur Glob. Cycles Scope Rep. 1976, 22, 75-88.

29. Broecker, W.S. Chemical Oceanography; Harcourt Brace Jovanowich Inc.: San Diego, CA, USA, 1976; ISBN 0-15-506437-1.

30. Desmidt, E.; Ghyselbrecht, K.; Zhang, Y.; Pinoy, P.; Van der Bruggen, B.; Verstraete, W.; Rabaey, K.; Meesschaert, B. Global Phosphorus Scarcity and Full-Scale P-Recovery Techniques: A Review. Crit. Rev. Environ. Sci. Technol. 2015, 45, 336-384. [CrossRef]

31. Søndergaard, M.; Jensen, J.P.; Jeppesen, E. Role of sediment and internal loading of phosphorus in shallow lakes. Hydrobiologia 2003, 506-509, 135-145. [CrossRef]

32. Scharf, W. Restoration of the highly eutrophic lingese reservoir. Hydrobiologia 1999, 416, 85-96. [CrossRef] 
33. Granéli, W. Internal phosphorus loading in Lake Ringsjön. In Nutrient Reduction and Biomanipulation as Tools to Improve Water Quality: The Lake Ringsjön Story; Hansson, L.A., Bergman, E., Eds.; Developments in Hydrobiology; Springer: Dordrecht, The Netherlands, 1999; Volume 140, pp. 19-26; ISBN 978-94-017-2462-3.

34. Bendoricchio, G.; Di Luzio, M.; Baschieri, P.; Capodaglio, A.G. Diffuse pollution in the Lagoon of Venice. Water Sci. Technol. 1993, 28, 69-78. [CrossRef]

35. Capodaglio, A.G.; Muraca, A.; Becchi, G. Accounting for water quality effects of future urbanization: Diffuse pollution loads estimates and control in Mantua's Lakes (Italy). Water Sci. Technol. 2003, 47, 291-298. [CrossRef] [PubMed]

36. Capodaglio, A.G.; Boguniewicz, J.; Llorens, E.; Salerno, F.; Copetti, D.; Legnani, E.; Buraschi, E.; Tartari, G. Integrated lake/catchment approach as a basis for the implementation of the WFD in the Lake Pusiano watershed. In Proceedings of the Conference on River Basin Management-Progress TOWARDS Implementation of the European Water Framework Directive; Scimago Lab: Budapest, Hungary, 2005; pp. 77-86.

37. Capodaglio, A.G.; Hlavínek, P.; Raboni, M. Physico-chemical technologies for nitrogen removal from wastewaters: A review. Rev. Ambient. Agua 2015, 10, 481-498. [CrossRef]

38. Capodaglio, A.G.; Hlavínek, P.; Raboni, M. Advances in wastewater nitrogen removal by biological processes: State of the art review. Rev. Ambient. Agua 2016, 11, 250-267. [CrossRef]

39. Capodaglio, A.G.; Ghilardi, P.; Boguniewicz-Zablocka, J. New paradigms in urban water management for conservation and sustainability. Water Pract. Technol. 2016, 11, 176-186. [CrossRef]

40. Capodaglio, A.G. Integrated, Decentralized Wastewater Management for Resource Recovery in Rural and Peri-Urban Areas. Resources 2017, 6, 22. [CrossRef]

41. Capodaglio, A.G.; Callegari, A.; Cecconet, D.; Molognoni, D. Sustainability of decentralized wastewater treatment technologies. Water Pract. Technol. 2017, 12, 463-477. [CrossRef]

42. Council Directive 91/271/EEC, Official Journal of the European Communities. 1991. 135/40. Available online: https:/ / eurlex.europa.eu/legalcontent/EN/TXT/PDF/?uri=CELEX:31991L0271\&from= EN (accessed on 20 April 2017).

43. Yang, L.; Zhou, H.; Moccia, R. Membrane Filtration Coupled with Chemical Precipitation to Treat Recirculating Aquaculture System Effluent. J. Environ. Qual. 2006, 35, 2419-2424. [CrossRef] [PubMed]

44. Barnard, J.L. A Review of Biological Phosphorus Removal in the Activated Sludge Process. Water SA 1976, 2 , 136-144.

45. Schoumans, O.F.; Rulkens, W.H.; Oenema, O.; Ehlert, P.A.I. Phosphorus Recovery from Animal Manure: Technical Opportunities and Agro-Economical Perspectives; Alterra Report; Alterra: Wageningen, The Netherlands, 2010.

46. Cornel, P.; Schaum, C. Phosphorus recovery from wastewater: Needs, techniques and costs. Water Sci. Technol. 2009, 59, 1069-1076. [CrossRef] [PubMed]

47. Donatello, S.; Cheeseman, C.R. Recycling and recovery routes for incinerated sewage sludge ash (ISSA): A review. Waste Manag. 2013, 33, 2328-2340. [CrossRef] [PubMed]

48. Mayer, B.K.; Baker, L.A.; Boyer, T.H.; Drechsel, P.; Gifford, M.; Hanjra, M.A.; Parameswaran, P.; Stoltzfus, J.; Westerhodd, P.; Rittmann, B.E. Total value of phosphorus recovery. Environ. Sci. Technol. 2016, 50, 6606-6620. [CrossRef] [PubMed]

49. Schipper, W.J.; Klapwijk, A.; Potjer, B.; Rulkens, W.H.; Temmink, B.G.; Kiestra, F.D.G.; Lijmbach, A.C.M. Phosphate recycling in the phosphorus industry. Environ. Technol. 2001, 22, 1337-1345. [CrossRef] [PubMed]

50. Sartorius, C.; von Horn, J.; Tettenborn, F. Phosphorus recovery from wastewater expert survey on present use and future potential. Water Environ. Res. 2012, 84, 313-322. [CrossRef] [PubMed]

51. Cost-Effective and Eco-Friendly Struvite Wastewater Treatment Products. Available online: http://www. struvite.info (accessed on 8 April 2018).

52. Borgerding, J. Phosphate deposits in digestion systems. J. Water Pollut. Control Fed. 1972, 44, 813-819.

53. Parsons, S.A. Recent scientific and technical developments: Struvite precipitation. CEEP Scope Newsl. 2001, 41, 15-22.

54. Le Corre, K.S.; ValsamieJones, E.; Hobbs, P.; Parsons, S.A. Phosphorus recovery from wastewater by struvite crystallization: A review. Crit. Rev. Environ. Sci. Technol. 2009, 39, 433-477. [CrossRef]

55. Le Corre, K.S.; Valsami-Jones, E.; Hobbs, P.; Parsons, S.A. Impact of calcium on struvite crystal size, shape and purity. J. Cryst. Growth 2005, 283, 514-522. [CrossRef] 
56. Crutchik, D.; Garrido, J.M. Struvite crystallization versus amorphous magnesium and calcium phosphate precipitation during the treatment of a saline industrial wastewater. Water Sci. Technol. 2011, 64, 2460-2467. [CrossRef] [PubMed]

57. Pastor, L.; Mangin, D.; Barat, R.; Seco, A. A pilot-scale study of struvite precipitation in a stirred tank reactor: Conditions influencing the process. Bioresour. Technol. 2008, 99, 6285-6291. [CrossRef] [PubMed]

58. Hao, X.D.; Wang, C.C.; Lan, L.; Van Loosdrecht, M.C.M. Struvite formation, analytical methods and effects of pH and Ca2+. Water Sci. Technol. 2008, 58, 1687-1692. [CrossRef] [PubMed]

59. Lee, S.; Yoo, B.; Lim, S.J.; Kim, T.; Kim, S.; Kim, J.Y. Development and validation of an equilibrium model for struvite formation with calcium co-precipitation. J. Cryst. Growth 2013, 372, 129-137. [CrossRef]

60. Peng, L.; Dai, H.; Wu, Y.; Peng, Y.; Lu, X. A comprehensive review of the available media and approaches for phosphorus recovery from wastewater. Water Air Soil Pollut. 2018, 229, 115. [CrossRef]

61. Liu, Y.H.; Rahman, M.M.; Kwag, J.H.; Kim, J.H.; Ra, C.S. Eco-friendly production of maize using struvite re- covered from swine wastewater as a sustainable fertilizer source. Asian Austral. J. Anim. Sci. 2011, 24, 1699-1705. [CrossRef]

62. Regy, S.; Mangin, D.; Klein, J.P.; Lieto, J. Phosphate Recovery by Struvite Precipitation in a Stirred Reactor, Phosphate Recovery in Waste Water by Crystallization; CEEP: Southampton, UK, 2002; pp. 54-58.

63. Yu, R.; Geng, J.; Ren, H.; Wang, Y.; Xu, K. Struvite pyrolysate recycling combined with dry pyrolysis for ammonium removal from wastewater. Bioresour. Technol. 2013, 132, 154-159. [CrossRef] [PubMed]

64. Shih, Y.J.; Abarca, R.R.M.; Luna, M.D.G.D.; Huang, Y.H.; Lu, M.C. Recovery of phosphorus from synthetic wastewaters by struvite crystallization in a fluidized-bed reactor: Effects of $\mathrm{pH}$, phosphate concentration and coexisting ions. Chemosphere 2017, 173, 466-473. [CrossRef] [PubMed]

65. Bojcevska, H.; Raburu, P.O.; Tonderski, K.S. Free water surface wetlands for polishing sugar factory effluent in western kenya-macrophyte nutrient recovery and treatment results. In Proceedings of the 10th International Conference on Wetland Systems for Water Pollution Control, Lisbon, Portugal, 23-29 September 2006; pp. 709-718.

66. Yuan, Z.; Pratt, S.; Batstone, D.J. Phosphorus recovery from wastewater through microbial processes. Curr. Opin. Biotechnol. 2012, 23, 878-883. [CrossRef] [PubMed]

67. Shilton, A.N.; Powell, N.; Guieysse, B. Plant-based phosphorus recovery from wastewater via algae and macrophytes. Curr. Opin. Biotechnol. 2012, 23, 884-889. [CrossRef] [PubMed]

68. Abis, K.L.; Mara, D.D. Primary facultative ponds in the UK: The effect of operational parameters on performance and algal populations. Water Sci. Technol. 2005, 51, 61-67. [CrossRef] [PubMed]

69. Yaakob, Z.; Kamarudin, K.F.; Rajkumar, R.; Takriff, M.S.; Badar, S.N. The current methods for the biomass production of the microalgae from wastewaters: An overview. World Appl. Sci. J. 2014, 31, 1744-1758. [CrossRef]

70. Garcia, J.; Mujeriego, R.; Bourrouet, A.; Penuelas, G.; Freixes, A. Wastewater treatment by pond systems: Experiences in Catalonia, Spain. Water Sci. Technol. 2000, 42, 35-42. [CrossRef]

71. Richmond, A. Handbook of Microalgal Culture: Biotechnology and Applied Phycology; Wiley-Blackwell: Hoboken, NJ, USA, 2004.

72. El Hamouri, B. Rethinking natural, extensive systems for tertiary treatment purposes: The high-rate algae pond as an example. Desalination Water Treat. 2009, 4, 128-134. [CrossRef]

73. Tarayre, C.; De, C.L.; Charlier, R.; Michels, E.; Meers, E.; Camargo-Valero, M.; Delvigne, F. New perspectives for the design of sustainable bioprocesses for phosphorus recovery from waste. Bioresour. Technol. 2016, 206, 264-274. [CrossRef] [PubMed]

74. Wang, X.; Chang, W.C.; Tang, C.Y. Osmotic membrane bioreactor (OMBR) technology for wastewater treatment and reclamation: Advances, challenges and prospects for the future. J. Membr. Sci. 2016, 504, 113-132. [CrossRef]

75. Qiu, G.; Ting, Y.P. Direct phosphorus recovery from municipal wastewater via osmotic membrane bioreactor (OMBR) for wastewater treatment. Bioresour. Technol. 2014, 170, 221-229. [CrossRef] [PubMed]

76. Achilli, A.; Cath, T.Y.; Marchand, E.A.; Childress, A.E. The forward osmosis membrane bioreactor: A low fouling alternative to MBR processes. Desalination 2009, 239, 10-21. [CrossRef]

77. Holloway, R.W.; Achilli, A.; Cath, T.Y. The osmotic membrane bioreactor: A critical review. Environ. Sci. Water Res. Technol. 2015, 1, 581-605. [CrossRef] 
78. Qui, G.; Zhang, S.; Raghavan, D.S.S.; Das, S.; Ting, Y. The potential of hybrid forward osmosis membrane bioreactor (FOMBR) processes in achieving high throughput treatment of municipal wastewater with enhanced phosphorus recovery. Water Res. 2016, 105, 370-382. [CrossRef]

79. Qiu, G.; Law, Y.M.; Das, S.; Ting, Y.P. Direct and complete phosphorus recovery from municipal wastewater using a hybrid microfiltration-forward osmosis membrane bioreactor process with seawater brine as draw solution. Environ. Sci. Technol. 2015, 49, 6156-6163. [CrossRef] [PubMed]

80. Luo, W.; Hai, F.I.; Price, W.E.; Guo, W.; Ngo, H.H.; Yamamoto, K.; Nghiem, L.D. Phosphorus and water recovery by a novel osmotic membrane bioreactor-reverse osmosis system. Bioresour. Technol. 2016, 200, 297-304. [CrossRef] [PubMed]

81. Thong, Z.; Cue, Y.; Ong, Y.K.; Chung, T.S. Molecular design of nanofiltration membranes for the recovery of phosphorus from sewage sludge. ACS Sustain. Chem. Eng. 2016, 4, 5570-5577. [CrossRef]

82. Hau, N.T.; Chen, S.S.; Nguyen, N.C.; Huang, K.Z.; Ngo, H.H.; Guo, W. Exploration of EDTA sodium salt as novel draw solution in forward osmosis process for dewatering of high nutrient sludge. J. Membr. Sci. 2014, 455, 305-311. [CrossRef]

83. Electric Power Research Institute (EPRI). Water \& Sustainability: U.S. Electricity Consumption for the Water Supply \& Treatment; The Next Half Century Topical Report; EPRI: Palo Alto, CA, USA, 2002.

84. De Haas, D.; Dancey, M. Wastewater treatment energy efficiency, a review with current Australian prospectives. AWA J. 2015. [CrossRef]

85. MURL-Ministry for Environment. Nature Protection, Agriculture E Consumer Protection in the German State of North Rhine Westphalia: Energy in WWTPs; MURL: Düsseldorf, Germany, 1999. (In German)

86. Gellings, C.W.; Parmenter, K.E. Energy Efficiency in Fertilizer Production and Use. Efficient Use and Conservation of Energy; Encyclopedia of life support systems (EOLSS): Oxford, UK, 2004; Volume 2.

87. Daw, J.; Hallett, K.; DeWolfe, J.; Venner, I. Energy Efficiency Strategies for Municipal Wastewater Treatment Facilities; NREL/TP-7A30-53341; National Renewable Energy Laboratory: Golden, CO, USA, 2012.

88. Vanrolleghem, P.A.; Vaneeckhaute, C. Resource Recovery from Wastewater and Sludge: Modelling and Control Challenges. In Proceedings of the IWA Specialist Conference on Global Challenges: Sustainable Wastewater Treatment and Resource Recovery, Kathmandu, Nepal, 26-30 October 2014.

89. Ráduly, B.; Gernaey, K.V.; Capodaglio, A.G.; Mikkelsen, P.S.; Henze, M. Artificial neural networks for rapid WWTP performance evaluation: Methodology and case study. Environ. Model. Softw. 2007, 22, 1208-1216. [CrossRef]

90. Vaneeckhaute, C.; Claeys, F.H.A.; Tack, F.M.G.; Meers, E.; Belia, E.; Vanrolleghem, P.A. Development, implementation, and validation of a generic nutrient recovery model (NRM) library. Environ. Model. Softw. 2018, 99, 170-209. [CrossRef]

91. Batstone, D.J.; Amerlinck, Y.; Ekama, G.; Goel, R.; Grau, P.; Johnson, B.; Kaya, I.; Steyer, J.-P.; Tait, S.; Takács, I.; et al. Towards a generalized physicochemical framework. Water Sci. Technol. 2012, 66, 1147-1161. [CrossRef] [PubMed]

92. Wett, B.; Buchauer, K.; Fimml, C. Energy self-sufficiency as a feasible concept for wastewater treatment systems. In Proceedings of the IWA Leading Edge Technology Conference, Asian Water, Singapore, 3-6 June 2007.

93. Chen, S.; Chen, B. Net energy production and emissions mitigation of domestic wastewater treatment system: A comparison of different biogas-sludge use alternatives. Bioresour. Technol. 2013, 144, 296-303. [CrossRef] [PubMed]

94. McCarty, P.L.; Kim, J.; Bae, J. Domestic wastewater treatment as a net energy producer e can this be achieved? Environ. Sci. Technol. 2011, 45, 7100-7106. [CrossRef] [PubMed]

95. Kelly, P.T.; He, Z. Nutrients removal and recovery in bioelectrochemical systems: A review. Bioresour. Technol. 2014, 153, 351-360. [CrossRef] [PubMed]

96. Capodaglio, A.G.; Molognoni, D.; Dallago, E. Microbial Fuel Cells for Direct Electrical Energy Recovery from Urban Wastewaters. Sci. World J. 2013, 634738. [CrossRef] [PubMed]

97. Capodaglio, A.G.; Molognoni, D.; Puig, S.; Balaguer, M.D.; Colprim, J. Role of Operating Conditions on Energetic Pathways in a Microbial Fuel Cell. Energy Procedia 2015, 74, 728-735. [CrossRef]

98. Liu, H.; Ramnarayanan, R.; Logan, B.E. Production of electricity during wastewater treatment using a single chamber microbial fuel cell. Environ. Sci. Technol. 2004, 38, 2281-2285. [CrossRef] [PubMed]

99. Cecconet, D.; Molognoni, D.; Callegari, A.; Capodaglio, A.G. Agro-food industry wastewater treatment with microbial fuel cells: Energetic recovery issues. Int. J. Hydrog. Energy 2018, 43, 500-511. [CrossRef] 
100. Kim, B.H. Microbial fuel cell. KISToday 2009, 2, 4-8.

101. Mo, W.; Zhang, Q. Energy-nutrients-water nexus: Integrated resource recovery in municipal wastewater treatment plants. J. Environ. Manag. 2013, 127, 255-267. [CrossRef] [PubMed]

102. Fischer, F.; Bastian, C.; Happe, M.; Mabillard, E.; Schmidt, N. Microbial fuel cell enables phosphate recovery from digested sewage sludge as struvite. Bioresour. Technol. 2011, 102, 5824-5830. [CrossRef] [PubMed]

103. Ichihashi, O.; Hirooka, K. Removal and recovery of phosphorus as struvite from swine wastewater using microbial fuel cell. Bioresour. Technol. 2012, 114, 303-307. [CrossRef] [PubMed]

104. Cusick, R.D.; Logan, B.E. Phosphate recovery as struvite within a single chamber microbial electrolysis cell. Bioresour. Technol. 2012, 107, 110-115. [CrossRef] [PubMed]

105. You, J.; Greenman, J.; Melhuish, C.; Ieropoulos, I. Electricity generation and struvite recovery from human urine using microbial fuel cells. J. Chem. Technol. Biotechnol. 2014, 91, 647-654. [CrossRef]

106. Jaffer, Y.; Clark, T.A.; Pearce, P.; Parsons, S.A. Potential phosphorus recovery by struvite formation. Water Res. 2002, 36, 1834-1842. [CrossRef]

(c) 2018 by the authors. Licensee MDPI, Basel, Switzerland. This article is an open access article distributed under the terms and conditions of the Creative Commons Attribution (CC BY) license (http://creativecommons.org/licenses/by/4.0/). 